\title{
The Development Strategy of Sustainable Bioethanol Industry on Iconic Sumba Island, Eastern Indonesia
}

\author{
Sawarni Hasibuan ${ }^{\#}$, Novizar Nazir ${ }^{*}$ \\ \# Industrial Engineering Department, Universitas Mercu Buana, Jakarta, Indonesia \\ E-mail: sawarni@mercubuana.ac.id \\ * Faculty of Agricultural Technology, Andalas University, Padang, Indonesia \\ E-mail:nazir_novizar@yahoo.com
}

\begin{abstract}
The development of biofuel industry in Indonesia represents the emerging phase, because of the impetus of government commitment to reduce greenhouse gas emission regulations which are decanted in President Decree No. 61 the year 2011. Indonesia has committed to reducing greenhouse gasses by $26 \%$ below 2005 levels, equivalent to 767 million tons of greenhouse gasses on their own. National Energy Policy set to blending bioethanol in premium 10\% and $20 \%$ in 2020 and 2050 respectively. Potency that owned by Sumba Island, especially in east eastern Indonesia, encourages the growth of bioethanol industry regarding the availability of raw material resources and tropical climate for biofuel crop cultivation. Therefore it is necessary to analyze the feasibility of bioethanol production from potential raw materials in Sumba Island. It combines a Bayes method with financial analysis and a Strengths, Weakness, Opportunities and Threats (SWOT) framework to propose the development strategy of sustainable bioethanol industry in the Sumba Island. Recommended feedstock for the development of the bioethanol industry in Sumba Island is sweet sorghum and cassava. Financial feasibility assessment of bioethanol industry is based on the assumption that at least $70 \%$ of the feedstock is supplied by the company's land and the rest comes from the farming communities. The proposed integration pattern is by integrating the ethanol industry with bio-farming and bio-manure to utilize the waste completely. The development of bioethanol industry in Sumba Island is still faced with many obstacles, including the sustainability of feedstock both for cassava and sweet sorghum, infrastructure constraints, and regulation enforcement. Alternative strategies for the development of an integrated bioethanol industry are (1) conducting intensification and extensification of agricultural land to meet the needs of raw materials, (2) promoting technological innovation and institutional innovation to accelerate the delivery and adoption bioethanol, and (3) developing bioethanol industry cluster that is supported by the infrastructure cluster.
\end{abstract}

Keywords - sustainable bioethanol industry; Bayes method; SWOT; sweet sorghum; Sumba island.

\section{INTRODUCTION}

Final energy consumption in Indonesia (including biomass) increased from 778 million BOE in 2000 to 1,211 million BOE in 2013, growing by an average of $3.46 \%$ per year [1]. Final energy consumption by type, during the years 2000-2013, was dominated by oil fuel (gasoline, diesel oil, IDO, kerosene, fuel oil, avtur, and avgas). During this period, the total oil fuel consumption increased by an average of $1.83 \%$ per year. In 2000 , the consumption of diesel oil has the largest share $(38.7 \%)$ followed by kerosene $(23.4 \%)$, gasoline (23.0\%), fuel oil (9.6\%), IDO (3\%) and avtur $(2.2 \%)$. Subsequently in 2013 the order is shifted into diesel oil $(45.4 \%)$, gasoline $(44.5 \%)$, avtur $(6.1 \%)$, kerosene $(1.9 \%)$, and fuel oil $(1.9 \%)$. The role of fossil fuels still dominates the energy utilization in Indonesia.
The Government has issued a National Energy Policy (KEN) as stipulated in Government Regulation No. 79/2014. KEN mandated a percentage of new and renewable energy (NRE) utilization in the national energy mix with a minimum of $23 \%$ in 2025 and $31 \%$ in 2050 [2]. With these targets, development of NRE can be optimized and at the same time, it can take advantage of environmentally friendly energy and support regional development in the remote and isolated area. The main intention of the regulation is to reduce the dependence of Indonesia on imported fossil fuel and cushion it from the erratic price fluctuations as well as ensure the availability of clean energy which can lead to reductions in Greenhouse Gas (GHG) emissions. The potential of biofuel from biomass is estimated at 32,654 MW, but currently, its utilization has reached 1,626 MW or approximately $4.98 \%$ of the existing potential [3]. Therefore, the development of biofuel is one of the main 
agenda of new and renewable energy development in Indonesia. Biofuel has a great potential for substitution of oil fuel in Indonesia, including in rural areas that have relatively low electrification ratio like Sumba Island.

Sumba Island, located in eastern Indonesia, has been chosen as the Iconic Island of 100\% Renewable Energy based on a study conducted by Hivos in 2010 together with Winrock International. The study shows that the island has low access to energy with electrification ratio of only $24.55 \%$ in spite of the island's great RE potential (water, the wind, and biofuel) [4]. The Asian Development Bank (ADB) in November 2012 and the Norwegian Embassy in 2013 have also assumed a role in supporting the implementation of Sumba Iconic Island program. In 2015, the program also gained support from the Millennium Challenge Account Indonesia (MCA-I) through the Green Prosperity program.

Sumba Iconic Island has achieved an important milestone with the Indonesian government's endorsement through the Ministerial Decree No. $3051 \mathrm{~K} / 30 / \mathrm{MEM} / 2015$ on 1 June 2015. The Decree is significant as a legal basis and acknowledgment of SII as a Ministry-led national program. However, it creates another challenge for all related stakeholders of the program as it sets a new ambitious goal to provide $95 \%$ RE-generated electrification access in Sumba Island by 2020 [5].

Among the various biofuels, fuel ethanol (bioethanol) is already commercially produced in many countries where it is used as an octane enhancer, blended with gasoline in various ratios to produce gasohol or used directly in specially designed ethanol engines. Ethanol fuel is widely used in Brazil and in the United States, and together both countries were responsible for $87 \%$ of the world's ethanol fuel production in 2012. The major users have also been the main producers of ethanol fuel. As of 2012, the United States ranked first in production (50.3 billion litres, or $61 \%$ of the market), followed by Brazil (21.1 billion litres, or $26 \%$ of the market), the European Union (4.5 billion litres, or $6 \%$ of the market) and China (2.1 billion litres, or $3 \%$ of the global market) [6].

Ethanol fuel has a specific energy value of $30 \mathrm{MJ} / \mathrm{kg}$ and an energy density of $24 \mathrm{MJ} / \mathrm{l}$ (gasoline has $46 \mathrm{MJ} / \mathrm{kg}$ and $36 \mathrm{MJ} / \mathrm{kg}$ respectively). Therefore, one liter of ethanol delivers $67 \%$ of the mileage delivered by the equivalent volume in gasoline when compared to gasoline [7]. Taking into consideration that gasoline is often sold already blended with ethanol, the energy density of the final blend is reduced. This has led to the establishment of a fuel economy parity threshold of 0.7 between ethanol and gasoline prices. In other words, about 0.7 liter of gasoline is necessary to produce the same energy (e.g. drive the same distance) as one liter of ethanol.

A large number of countries have already adopted some kind of biofuel blend (either ethanol or biodiesel) into their conventional fuel pools [8-9]. Gasoline is rarely sold in its pure form, but instead blended with fossil oxygenates which enhance engine fuel performance. Based on well-known production methods, ethanol is often the biofuel of choice for initial blending in many countries. The deployment of ethanol occurs mainly through the substitution of gasoline performance-enhancers (oxygenates) MTBE or ETBE [10].
The most common pathway for the introduction of ethanol in a national energy matrix is by mixing small volumes of ethanol directly with gasoline, producing what is known as low ethanol blends (E5-E25). This pathway is often preferred partially due to the fact that any ethanol supply disruptions at low-blend scales could be compensated with an increased proportion of gasoline to dampen overall impact. At the same time, small percentage blending (e.g. up to $10 \%$ ) can be done with relative technical ease, substituting fossil oxygenates such as MTBE, and avoiding the need for costly adaptations in automotive engines, fuel storage, transport and fuel infrastructure [11].

Bioethanol can be produced from a number of agricultural feedstock. Raw materials investigated or already used for commercial production of fuel ethanol include sugar crops such as sugar cane, sugar beet, and sweet sorghum [12]; cereals such as corn, millet, and sorghum [13]; root crops such as potatoes, sweet potatoes, sago, and cassava [14-15]; molasses, as well as various types of lignocellulose materials [16-19].

Most of the traditional crops used to produce ethanol have dual usage as food, causing concerns as demand for biofuels grow [20]. Indonesian policy direction in the development of energy feedstock is the availability of alternative energy from biofuel in a sustainable, decentralized and integrated into the activities on the farm and off farm through efficient resource utilization that is supported by science and technology. The development of the bioethanol industry in Sumba Island needs to be done in an integrated way from upstream to downstream in order to ensure its sustainability. Therefore, it needs to be analyzed on the feasibility of the establishment of bioethanol industry in Sumba Island and it's development strategy so that sustainability can be maintained. The objective of this research was to analyze the strategy for sustainable development of bioethanol industry in Sumba Island, Eastern Indonesia.

\section{MATERIAL AND METHOD}

This research was conducted in three stages, namely 1) the prioritization of feedstock for bioethanol production in Sumba Island, 2) feasibility analysis of establishing bioethanol industry based on selected feedstock, and 3) development strategy of sustainable bioethanol industry in Sumba Island. Prioritization of feedstock for bioethanol production on the Sumba Island conducted using Bayes method. Making decisions with Bayes method is done through the efforts to quantify the likelihood of an event and expressed with a number between 0 and 1 or scale conversions [21-22]. But often it is regarded as a personal or subjective probability Bayes where weights are based on the level of trust, confidence, experience and background of the decision makers. Bayes equation used to calculate the value of each alternative are often simplified to:

Total Value ${ }_{-\mathrm{i}}=\sum \mathrm{W}_{\mathrm{i}} \operatorname{Scor}_{-\mathrm{ij}}\left(\right.$ criterion $\left.^{\mathrm{th}}\right)$

where:

Total Value i: the final total score of alternative to- $\mathrm{i}$

Score ${ }_{-\mathrm{ij}}$ : the score of alternative to-i on the criterion to-j

Criterion ${ }_{\mathrm{j}}$ : weighting of criterion to-j

$\mathrm{i}: 1,2,3, \ldots \mathrm{n} ; \mathrm{n}=$ sum of the alternative

$\mathrm{j}: 1,2,3, \ldots \mathrm{m} ; \mathrm{m}=$ sum of the criterion 
Value opportunities obtained from an initial information that can be subjective and objective. The value of these opportunities can be improved by their additional information obtained from a number of experiments. Initial information about the value of this opportunity is called prior distribution, while the value of opportunities is being improved with additional information called posterior opportunities.

To evaluate the feasibility of bioethanol establishments on the Sumba Island referring to the financial eligibility criteria such as NPV, IRR, B/C, and payback period. Estimated capital and per unit variable costs for producing ethanol from feedstock were obtained from Indonesia ethanol industry experts compare to market price. Capital costs for the corn feedstock scenario were estimated at $\$ 2.25$ per gallon of ethanol capacity, while per unit non-corn variable costs were estimated by inflating 2006 costs reported by BPPT [23]. Capital costs in each scenario are fully amortized over a 20 year period at 12 percent fixed interest. Processing inputs include enzymes, labor, administrative costs, maintenance, water, denaturant, electricity, and natural gas.

The key tool used in planning the sustainable bioethanol industry development in Sumba Island is Strengths, Weaknesses, Opportunities and Threat (SWOT) analysis, which originates from the business management literature and was adopted in the 1980 s by public administration across such areas as regional development and municipal planning [24-26]. Specifically, there have been several examples of successful application of SWOT analyses in the fields of regional energy planning [27] and municipal solid waste management [28]. A number of European countries used SWOT analysis for selection of policy priorities and ensuring horizontal policy coherence in their national strategies for sustainable development [29-30].

In this paper, the list of SWOT is developed in a participatory approach (bottom-up component), complemented with a study of the existing relevant strategic and planning documents, legislation and statistics (top-down component), so that the final results are a common understanding of reality and a set of common strategic actions.

\section{RESULTS AND DISCUSSION}

The selection of Sumba Island as a Renewable Energy Iconic Island is based on the magnitude potential of new and renewable energy in Sumba which can be used as one of the main driving wheels for the economic community on Sumba Island. The development program on Sumba Island as a Renewable Energy Iconic Island aims to provide access to reliable energy to the community who live in small and medium size islands in Indonesia. It is conducted through the exploitation of renewable energy with a target by $100 \%$ in the realization of the energy availability that comes from renewable energy in 2025.

\section{A. Feedstock Priority}

The choice of feedstock is very crucial in the commercial production of fuel ethanol since the cost of feedstock makes up a significant percentage of the total production cost. Technological issues such as the ease of which the material can be converted to ethanol, the ethanol yield and productivity are taken into consideration in the choice of the feedstock for fuel ethanol production. The choice of the feedstock depends on the suitability of available land for their production, the productivity of the crop, the production cost (requirement for fertilizers, and other agrochemicals), environmental sustainability of the crop, social factors (food use and the effects on the prices of food), and on the whole, the economic feasibility. For example, while sugar cane is the main substrate used for bioethanol production in Brazil, most ethanol produced in the United States is from corn.

Economic research has explored various alternative ethanol production technologies. Progress has been made with respect to biochemical and thermochemical technologies for cellulosic ethanol, yet the ability to reach commercial viability continues to elude the industry. Some researchers have examined the economic feasibility of ethanol production from grain sorghum and corn, sugar, sugarcane juice and molasses, sugar, and sugarcane juice, respectively [31-36]. Studies by Epplin [37], Graham et al. [38], and Mapemba et al. [39] have explored transportation, harvest, and delivered feedstock cost components of biomass used for cellulosic ethanol. Outlaw et al. [31] conclude ethanol production from sugarcane juice, a predominant production method in Brazil would be economically feasible in certain regions of the United States. Brazil has demonstrated that sugarcane can be used directly as a raw material in ethanol production. However, sugar policy has left little opportunity for this method to gain traction in the United States.

Sweet sorghum, grown as an alternative to sugarcane, has been identified as a potential dedicated energy crop that can be grown as far north and south as latitude $45^{\circ}[32,35]$. During very dry periods, sweet sorghum can go into dormancy, with growth resuming when sufficient moisture levels return [40-41]. Ethanol can be produced from either the grain of sweet sorghum or from its sweet stalk juice. The grain is processed in the same way as corn in the dry milling process while the stalk undergoes the same process as that for cane sugar ethanol production. Sweet sorghum is comparable with other types of feedstock in terms of yield, bioethanol productivity, and cost. The ethanol yield of sweet sorghum per hectare is comparable with corn and cassava but lower than sugarcane. But in terms of bioethanol productivity, that is the ethanol yield per ton of feedstock, sweet sorghum is the most productive with a production of $4251 /$ ha ( $501 /$ ton from the stalk and $3751 /$ ton from grains). Sweet sorghum is cost competitive compared to molasses, corn, and cassava and with sugarcane for cane-extracted alcohol but not for rain-extracted alcohol.

Bioethanol production from cassava has very high potential in Sumba Island as well as in many tropical countries because of its ability to give moderate yield even in poor soils. Although cassava yield per hectare is still low in Sumba Island (about $11 \mathrm{ton} / \mathrm{h}$ ), Indonesia has remained the third largest cassava producing country in the world [42]. Cassava can be grown on marginal lands where other crops cannot grow. It is, therefore, suitable for poor rural farmers who cannot afford to buy fertilizers for increased yield. In addition, it can be cultivated two to three times in a year since it does not require so much rain [43]. 
Cassava is the third most important source of calories in the tropics, after rice and maize. The broad agro-ecological adaptability of cassava and its ability to produce reasonable yields where most crops cannot make it the basis for food security at the household level and an important source of dietary energy. It is widely cultivated in tropical and subtropical regions of the world it is mainly cultivated in Africa, Asia, and Latin America, a report said that the world is producing around 250 million tons of cassava every year. It is estimated that African countries are producing more than half of the total world production of Cassava, secondly Asia and then Latin America, Nigeria is leading the world in the production of cassava with its annual production of 52 million tons. Indonesia ranks world's third largest producer of cassava with the production of 24.009 .624 tons in 2015 [42].

Feedstock for bioethanol features inventoried area of land including aspects of technology, infrastructure, production, and investment as well as regional government policy in Sumba Island. The criteria used to determine the priority of feedstock for bioethanol processing on Sumba island include (1) the availability of existing land, (2) the availability of areas for development, (3) the plant productivity, (4) the accessibility and availability of production facilities, (5) the farmers' skills in planting and harvesting the crops, (6) the function of plant as food, (7) the yield of ethanol from raw materials, and (8) the support from capital financing. All of the criteria are based on the results of field observation, literature review and deep interviews with selected stakeholders on Sumba Island. The alternatives of feedstock for bioethanol that have been analyzed are cassava, sweet potato, corn and sweet sorghum (Table I).

Based on Bayes method on Table I, the priorities of feedstock for bioethanol industry on Sumba Island are sweet sorghum, cassava, corn, and sweet potatoes. Out of the four alternative feedstock, sweet sorghum and cassava have the highest score; therefore, they will encourage the development of the bioethanol industry on Sumba Island. As recommended by the Ministry of Agriculture, intensification, and extensification of the cultivation of cassava and sweet sorghum are suitable as feedstock of bioethanol in Eastern Indonesia. The cultivation of cassava and sweet sorghum has been done since long time ago by the community of Sumba Island, NTT Province, but it is still done traditionally without intensive coaching from local governments. The average yield of cassava production of communities in NTT is in the range of 100-120 quintals/ ha/year, far below the national average productivity which is 20 tons/ha/year. If the cassava cultivation is conducted intensively in accordance with the results of the field test, it will be capable of producing more than 100 tons/ha/year.

In this analysis, it is assumed that moderate cassava productivity is 30 tons/ha/year. For sweet sorghum commodities, it is assumed that sweet sorghum stem production is 40 tons/ha/harvest. It is also assumed that there are 2 times of harvesting per year, bringing a total production of 80 tons of sweet sorghum stems /ha/year.

\section{B. The Capacity of Bioethanol Production}

The BPH Oil and Gas recorded the data that the subsidized fuel quota on Sumba Island for premium gasoline amounted to $29,280 \mathrm{KL}$ of the total NTT Province which stood at $265,217 \mathrm{KL}$, diesel by $17,837 \mathrm{KL}$ of total NTT Province amounted to $135.425 \mathrm{KL}$, and kerosene by 9,064 KL of total NTT Province which achieved 96.923 KL. Bioethanol plant planned to be built on Sumba Island is using the base scenario; that is $30,000 \mathrm{~L} /$ day or 9,000 KL/year, assuming $300 \mathrm{HK} /$ year.

TABLE I

The Assessment of Alternative Bioethanol FeEdstock Through BAYES METHOD ON SUMBA ISLAND

\begin{tabular}{|c|c|c|c|c|c|c|}
\hline \multirow[b]{2}{*}{ No } & \multirow[b]{2}{*}{ Criteria } & \multirow[b]{2}{*}{ Weight } & \multicolumn{4}{|c|}{ Probability } \\
\hline & & & $\begin{array}{c}\text { Sweet } \\
\text { Sorghum }\end{array}$ & Cassava & Corn & $\begin{array}{l}\text { Sweet } \\
\text { Potato }\end{array}$ \\
\hline 1 & $\begin{array}{l}\text { The } \\
\text { availability of } \\
\text { existing land } \\
\end{array}$ & 0.16 & 0.6 & 0.4 & 0.4 & 0.4 \\
\hline 2 & $\begin{array}{l}\text { The availabi- } \\
\text { lity of areas for } \\
\text { development }\end{array}$ & 0.16 & 0.6 & 0.4 & 0.4 & 0.4 \\
\hline 3 & $\begin{array}{l}\text { The plant } \\
\text { productivity }\end{array}$ & 0.06 & 0.8 & 0.6 & 0.8 & 0.6 \\
\hline 4 & $\begin{array}{l}\text { The } \\
\text { accessibility } \\
\text { and availability } \\
\text { of production } \\
\text { facilities }\end{array}$ & 0.04 & 0.6 & 0.4 & 0.4 & 0.3 \\
\hline 5 & $\begin{array}{l}\text { The farmers' } \\
\text { skills in } \\
\text { planting and } \\
\text { harvesting the } \\
\text { crops }\end{array}$ & 0.04 & 0.6 & 0.6 & 0.6 & 0.5 \\
\hline 6 & $\begin{array}{l}\text { The function of } \\
\text { the plant as } \\
\text { food }\end{array}$ & 0.16 & 0.6 & 0.6 & 0.4 & 0.6 \\
\hline 7 & $\begin{array}{l}\text { The yield of } \\
\text { ethanol from } \\
\text { feedstock }\end{array}$ & 0.16 & 0.4 & 0.6 & 0.6 & 0.4 \\
\hline 8 & $\begin{array}{l}\text { The support } \\
\text { from capital } \\
\text { financing }\end{array}$ & 0.04 & 0.4 & 0.4 & 0.3 & 0.3 \\
\hline & Total Value & & 0.392 & 0.460 & 0.388 & 0.348 \\
\hline & Ranking & & 2 & 1 & 3 & 4 \\
\hline
\end{tabular}

If it is assumed that bioethanol production could support mandatory fuel blending E-5 in 2020, the bioethanol industry with a capacity of 9,000 KL/year will have been able to meet the needs of "blending" for the island of Sumba in the amount of $1,464 \mathrm{KL} / \mathrm{year}(\mathrm{E}-5)$ or it is equivalent amount of substituting the blending needs of E-5 in NTT that reach $67.9 \%$ (E-5 blending needs in NTT Province is 13 $261 \mathrm{KL} / \mathrm{year}$ ). If we use the commercial skills of bioethanol industry which reach $18.000 \mathrm{KL} /$ year as stated by BPPT, the production of bioethanol is capable of substituting subsidized fuel in NTT Province. If sweet sorghum feedstock is used, the need for bioethanol industry with a production capacity of $9,000 \mathrm{KL} /$ year or $3,000 \mathrm{KL} /$ day is equal to 1,744 hectares (assuming a ratio of sweet sorghum stalks: bioethanol $99.5 \%=15.5: 1$ in which the production of sweet sorghum stalk reaches 40 tons/ha/harvest and 2 times of harvesting per year). To supply the bioethanol production as many as $30 \mathrm{KL} / \mathrm{year}$, it requires 465 tons of sorghum stalks/day or 139,500 tons of stalks of 
sorghum/year (300 HK). If the productivity of land reaches 80 tons of sorghum stem per year, the need of land for the cultivation of sweet sorghum will be 1,744 hectares for the capacity of $9,000 \mathrm{KL} /$ year or a total of 3,488 hectares for a capacity of $18,000 \mathrm{KL} /$ year.

\section{Financial Aspect}

Financial feasibility assessment of bioethanol industry based on the assumption that the supply of feedstock, that is sweet sorghum or cassava, is at least $70 \%$ of the demand. It must be provided by our own garden and the rest, a maximum of $30 \%$ comes from farming communities. This assumption is used considering the stability of raw material supply in the future. Therefore, for the capacity of bioethanol industry that stands at $30,000 \mathrm{KL}$ per day, the composition of the land required by the company is at least 1 . 221 hectares if sorghum commodity is used, or 1.313 hectares if cassava commodity is used. Meanwhile, the community needs about 523 hectares of land if the feedstock is sweet sorghum, or about 563 hectares if the feedstock is cassava.

Financial feasibility calculations were done separately; these are the farming activity of sweet sorghum commodities and the farming activity of cassava commodities by farmers. Financial analysis on the farm of sweet sorghum and cassava farming is used for 1 hectare of land area. Meanwhile, bioethanol industrial analysis, which is integrated with sweet sorghum and cassava feedstock, uses base scenario production capacity of 3,000 KL bioethanol/day or 9,000 KL bioethanol/year, assuming $300 \mathrm{HK}$ production of bioethanol per year.

Financial feasibility analysis on the establishment of bioethanol industry which is integrated with sweet sorghum feedstock is carried out by using the assumptions in Table II.

Planning the needs of investment costs for bioethanol industry is based on the historical investment by other similar companies, and the data of major equipment price come from the vendor. The total cost for the investment of equipment and non-physical bioethanol plant with a capacity of $90,000 \mathrm{KL} /$ year is IDR 53,061,958,475 which includes the cost of engineering design and contingencies (Table II and Table III).

The accounting result for the Internal Rate of Return (IRR), Net B/C, and Payback Period for the investment of bioethanol with the capacity of 9,000 KL/year, which utilizes feedstock and sorghum, is summarized in Table IV. Financially the setup of the integrated bioethanol technology on Sumba Island is liable with the IRR to score around 19\% up to $26 \%$ with the return period as long as 4-6 years. Based on the accounting, we get the net $\mathrm{B} / \mathrm{C}$ ratio as high as 1.85 which indicates that the project is liable to run because the ratio is higher than 1.0.

\section{SWOT (Strengths, Weaknesses, Opportunities, Threats) Analysis}

Based on the internal and external strategy analysis, SWOT analysis matrix is aimed to get some alternative strategies (Table V). SWOT matrix is an important matching tool in developing the four types of strategies: SO, WO, ST and WT (Table VI).
TABLE II

The Profile of CASSAVA-SWEET SORGHUM Plant ON SUMBA ISLAND

\begin{tabular}{|c|c|c|c|}
\hline \multirow{2}{*}{ No } & \multirow{2}{*}{ Description } & \multicolumn{2}{|c|}{ Raw Material } \\
\hline & & Cassava & Sweet sorghum \\
\hline 1 & $\begin{array}{l}\text { Plant capacity/year } \\
(90,000 \mathrm{~K} \mathrm{~L} / \text { year })\end{array}$ & $\begin{array}{c}9,000 \\
\text { KL/year }\end{array}$ & 9,000 KL/year \\
\hline 2 & Types of ethanol & $\begin{array}{c}\text { Ethanol } \\
99.5 \% \mathrm{v} / \mathrm{v}\end{array}$ & $\begin{array}{c}\text { Ethanol } 99.5 \% \\
\mathrm{v} / \mathrm{v}\end{array}$ \\
\hline 3 & Feedstock & Flour & $\begin{array}{c}\text { Seeds + Sorghum } \\
\text { stalks }\end{array}$ \\
\hline 4 & $\begin{array}{l}\text { Starch/sugar content } \\
\text { - Stalks } \\
\text { - Seeds/ Tuber }\end{array}$ & $25 \%-30 \%$ & $\begin{array}{l}11 \% \\
62 \%\end{array}$ \\
\hline 6 & $\begin{array}{l}\text { Materials }(\mathrm{kg}) \text { : ethanol } \\
\text { (liter) } \\
\text { - }\end{array}$ & $6.25: 1$ & $\begin{array}{c}20: 1 \\
3,2: 1\end{array}$ \\
\hline 7 & Harvest Period & 9 months & 4 months \\
\hline 8 & $\begin{array}{l}\text { Production (t/ha) per } \\
\text { year } \\
\text { - Stalks } \\
\text { - Seeds }\end{array}$ & $20-40$ ha & $\begin{array}{l}40-50 \text { ton } \\
10-16 \text { ton }\end{array}$ \\
\hline 9 & $\begin{array}{l}\text { Ethanol } \\
\text { production/ha/year }\end{array}$ & $\begin{array}{c}3,200-7,200 \\
\text { L/ha }\end{array}$ & $5,000 \mathrm{~L} / \mathrm{ha}$ \\
\hline 10 & $\begin{array}{l}\text { Cost/L (Bloomberg, } \\
\text { 2013) }\end{array}$ & US\$ 0.6 & US\$ 0.51075 \\
\hline
\end{tabular}

TABLE III

THE ACCOUNTING OF INVESTMENT NEEDED FOR BIOETHANOL PROJECT OF SWEET SORGHUM WITH THE CAPACITY OF 9000 KL/YEAR

\begin{tabular}{|l|r|}
\hline Fixed Capital & IDR \\
\hline Main equipment & $28,500,000,000$ \\
\hline Feeder & $10,500,000000$ \\
\hline Waste processing unit & $500,000,000$ \\
\hline Land, 10 Ha & $500,000,000$ \\
\hline Building for factory and office & $1,500,000,000$ \\
\hline Engineering Design & $300,000,000$ \\
\hline Contingency & $830,000,000$ \\
\hline Total Fixed Capital & $40,498,500,000$ \\
\hline Interest During Construction (IDC) & $2,551,405,500$ \\
\hline Total Fixed Capital + IDC & $43,049,905,500$ \\
\hline Permit & $2,000,000,000$ \\
\hline Work Capital & $8,012,052,975$ \\
\hline Total Investment & $53,061,958,475$ \\
\hline
\end{tabular}

TABLE IV

The ACCOUNTING RESUlt OF IRR, NET B/C, AND PBP BIOETHANOL INVESTMENT WITH THE CAPACITY OF 9000 KL/YEAR

\begin{tabular}{|l|c|c|c|c|}
\hline Feedstock & IRR & Net B/C & PBP & Decision \\
\hline Sweet Sorghum & $26.4 \%$ & 1.85 & 4.02 year & Feasible \\
Cassava & $19.2 \%$ & 1.87 & 5.41 year & Feasible \\
\hline
\end{tabular}

The strategy of developing bioethanol industry based on feedstock such as cassava and sweet sorghum on Sumba Island in the Province of NTT is facing some obstacles such as the aspects of feedstock supply, infrastructure, and regulation. Related to feedstock, the problem is continuity or feedstock availability of cassava or sweet sorghum. In 
connecting with the infrastructure, the obstacle is repairing the condition of infrastructure utility and energy. Considering the regulation, there is an implementation incentive of investment policy on bioethanol industry on Sumba Island.

TABLE V

SWOT MATRIX OF THE DEVELOPMENT OF BIOETHANOL INDUSTRY ON SUMBA ISLAND

\begin{tabular}{|c|c|}
\hline $\begin{array}{l}\text { Strengths } \\
\text { 1.The Suitability and availability of } \\
\text { land for cassava and sweet } \\
\text { sorghum farming activity } \\
\text { 2. The Skill and experience for } \\
\text { farming industry } \\
\text { 3. The characteristic of farming land } \\
\text { ownership as the farmer who } \\
\text { possesses the land } \\
\text { 4.The potency of bioethanol } \\
\text { industry integration with the } \\
\text { local farming activity }\end{array}$ & $\begin{array}{l}\text { Weaknesses } \\
\text { 1.The potency of local market is } \\
\text { limited } \\
\text { 2.Raw material productivity is } \\
\text { low } \\
\text { 3.Technology mastery of the local } \\
\text { human resources is limited } \\
\text { 4.The infrastructure is limited } \\
\text { 5.There is no incentive scheme } \\
\text { for bioethanol development }\end{array}$ \\
\hline Opportunities & 101 \\
\hline $\begin{array}{l}\text { 1. Sumba Island is potential to } \\
\text { produce bioethanol products }\end{array}$ & $\begin{array}{l}\text { 1.The Feedstock competes with } \\
\text { food industry }\end{array}$ \\
\hline $\begin{array}{l}\text { 2.There is government policy of } \\
\text { EBT and bioethanol }\end{array}$ & $\begin{array}{l}\text { 2.Feedstock continuity is not } \\
\text { assured }\end{array}$ \\
\hline $\begin{array}{l}\text { 3.There is regional and national } \\
\text { market potency }\end{array}$ & $\begin{array}{l}\text { 3. There are institutional obstacles } \\
\text { (permit and bureaucracy) }\end{array}$ \\
\hline 3.Sumba island is chosen as EBT & 4.The BBN usage is not popular \\
\hline & \\
\hline $\begin{array}{l}\text { 4. The elimination of subsidized } \\
\text { fuel makes the price of } \\
\text { bioethanol competitive }\end{array}$ & \\
\hline
\end{tabular}

Some other obstacles for the development of bioethanol industry are: the high production cost for small industry scale, the higher price of bioethanol per litre compared to subsidized gasoline (BBM), the limited number of human resources who master technology, the competition between feedstock and food industry, institutional obstacles (permit and bureaucracy), and the declining quality of natural resources. By means of strong industrial institutions, the obstacles can be overcome well [33]. It is supported by BPPT [26] who said that the focus of attention for developing industry are technology and institutions which suited with the environment supportive power.

TABLE VI

THE DEVELOPMENT STRATEGY OF BIOETHANOL INDUSTRY ON SUMBA ISLAND

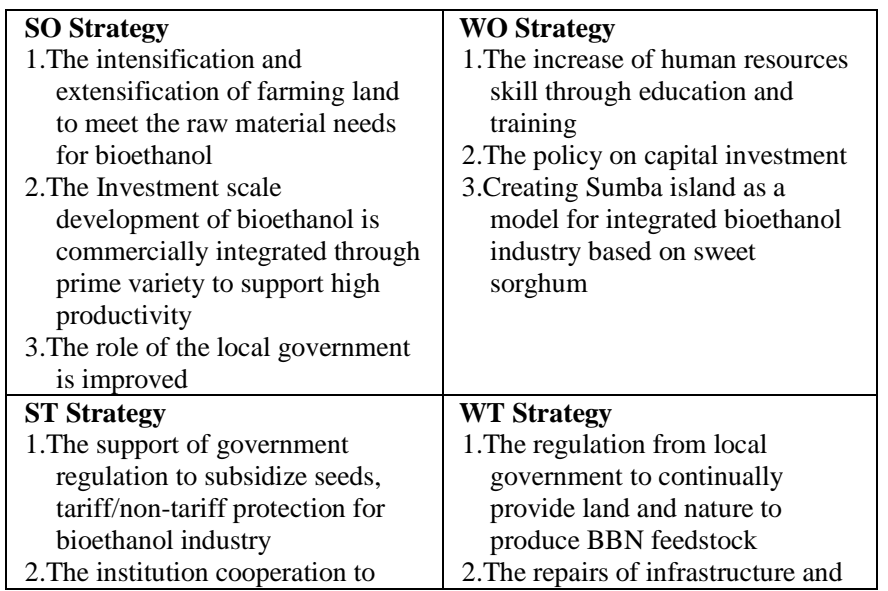

$\begin{aligned} & \text { continually provides bioethanol } \\ & \text { feedstock }\end{aligned}$
3.The socialization of bioethanol
utilization which applies SHE
(Safety Health Environment) to
the community

The main requirements to develop sustainable bioenergy industry are market assurance and price stability [44-45]. The strategies to meet the crucial aspects can be performed by improving the capacity or farmer's skill in applying cultivation technology of cassava \& sweet sorghum. To improve farmer's capacity, farmers and bioethanol industry business practitioners are involved in the training of farming prime varieties of cassava and sweet sorghum. In order to get a high scale of productivity, farmers are also trained to develop the capacity of supplying seeds of cassava and sweet sorghum and processing bioethanol industry side products for fertilizer and food. In addition to improving farmers capacity, it is important to enhance the organization at the farmer level, so that development activity for technology transfer is more conducive. Training operation can be done in cooperation with the experts coming from The technology of sweet sorghum plant cultivation, Department of Agriculture (superior varieties of cassava and sweet sorghum), Department of Industry, Research and Development and/or Universities.

The other needs are developing the quality of human resources, improvement of infrastructure, bioethanol distribution policy, investment protection assurance, improvement of technology resources, the intensification of cassava and sweet sorghum, and the availability of subsidy and incentive from the government. The purpose of improving the human resources quality is to increase farmers' capacity, not only in the farming technology of cassava and sweet sorghum but also in seed technology and the most recent technology innovation for the development of bioethanol industry for commercial scale. Those factors can function optimally if they are supported by the government and the business practitioners themselves in providing skillful human resources and institutional management which supply feedstock and bioethanol distribution mechanism on Sumba Island.

\section{F. The Strategy of Developing Institutions for Bioethanol Industry}

The basic need in developing bioethanol industry, which is based on cassava and sweet sorghum feedstock, depends on the development of potential capital. Some of them are comparative primary, internal factor, external factor, related elements' role, and institution. The comparative primary includes land availability for raw materials such as cassava and sweet sorghum. The land is quite spacious and scattered all over the Sumba Island. Another comparative advantage is the high adaptation level of cassava and sweet sorghum in a dry area. They can grow in the less fertile land. They are easy to handle, multifunction and scores high as productive biofuel.

The internal factors are the power that exists inside the organizations themselves, and they can be controlled by the 
management. They also directly influence bioethanol industry performance which will be developed such as, the availability of skillful human resources and infrastructure, the characteristic of social economy, the institutions and demography of Sumba Island community. The external factors are the power outside of the company's ability and control which directly influence bioethanol industry performance that will be developed. They include suppliers, customers, broker institutions, competitors, community needs and policies [30, 33].

There are roles of performer elements which are related to bioethanol industry development on Sumba Island. The elements are a community, an association of biofuels, bioethanol businessmen, related industries (food and feed), the government, research and development, and universities. Those elements need to be synergized cooperation to accelerate bioethanol industry development on Sumba Island within one institution.

\section{CONCLUSIONS}

Generally, the community on Sumba Island welcomes the setup of bioethanol product. On the other hand, the aspects of social culture that must be taken into consideration are the misuse of bioethanol products by the inhabitants and their culture to clear the land during the dry season. The development of bioethanol industry is integrated with the farming activity of cassava and sorghum. It is financially liable considering the financial aspect in which the IRR scores range around $20.43 \%-33.91 \%$, with net $\mathrm{B} / \mathrm{C} 1.32 \%$ $1.67 \%$, and the payback period is as long as 3-3.9 years. Alternative strategies for the development of integrated bioethanol industry on Sumba Island are as follows: 1) performing intensification and extensification of the land for cassava and sweet sorghum, 2) empowering the technological and institutional innovations to speed up the process of distribution and the adoption of bioethanol technology, and 3) developing bioethanol industry clusters which are supported by superstructures and infrastructures. The government needs to provide a special fiscal facility for the investors who want to invest in the integrated bioethanol industry on Sumba Island. The local government of Sumba Island must improve the facilities and infrastructures such as roads and electricity, and provide the educated skillful workforce to support integrated bioethanol development on Sumba Island.

\section{REFERENCES}

[1] Sugiyono, A., Anindhita, Boedoyo, and Adiarso [ed.]. (2015). Indonesia Energy Outlook 2015: Energy Development in Supporting Sustainable Development. Center for Energy Resources Development Technology, Jakarta.

[2] Regulation of The Government of The R.I. Number 79 The year 2014 Concerning The National Energy Policy

[3] Budiman, A. (2014). Potensi Pengembangan Bio-Compressed Methane Gases (Bio-CMG) dari Biomassa sebagai Pengganti LPG dan BBG. Presented in Seminar Nasional Pemanfaatan Gas Alam menuju Kedaulatan Energi Indonesia Yogyakarta, 25 Agustus 2014.

[4] Hivos. (2012). Sumba: an IconIc Island to demonstrate the potential of renewable energy. The Hague, The Netherlands.

[5] Asian Development Bank. (2015). Proposed Programmatic Approach and Policy-Based Loans for the Subprogram 1 Republic of Indonesia: Sustainable and Inclusive Energy Program. Project Number: 49043-001.
[6] REN21 (2012). Renewable Energy Policy Network for the 21st Century: Global Status Report. Paris, REN21 Secretariat.

[7] Pacini, H. (2015). The Development of Bioethanol Markets under Sustainability Requirements. Thesis. School of Industrial Engineering and Management Department of Energy Technology, Sweden.

[8] UNCTAD. (2014). Second Generation Biofuel Markets: State of Play, Trade and Developing Country Perspectives. UNCTAD Secretariat, Geneva.

[9] Mojarro, N. (2014). Ethanol and oil firm: the beginning of a new role for alternative fuels. Oxford Institute for Energy Studies, Oxford.

[10] Szklo, A., Schaeffer, R., and Delgado, F. (2007). Can one say ethanol is a real threat to gasoline?, Energy Policy, 35, 5411-21

[11] Hansen, Alan C., Qin Zhang, Peter, W.L. Lyne. (2005). Ethanoldiesel fuel blends - a review. Bioresource Technol, 96, 277-285

[12] Ogbonna, C.N., and Okoli, E.C. (2013). Economic feasibility of onfarm fuel ethanol production from cassava tubers in rural communities. African Journal of Biotechnology 12(37): 5618-5626.

[13] Montesinos, T., Navarro J.M. (2000). Production of alcohol from raw wheat flour by amyloglucosidase and Saccharomyces cerevisiae. Enzyme Microb. Technol. 72:261-266.

[14] Dai, A. et al. (2006). Recent Trends in Cloudiness Over The United States. American Meteorology Association 597-606.

[15] Bengoa, M. and Sanchez-Robles, B. (2003). Foreign direct investment, economic freedom, and growth: new evidence from Latin America. European Journal of Political Economy 19: 529-545.

[16] Sun, Y. and Cheng, J. (2002). Hydrolysis of lignocellulosic material for ethanol productive: a review. Bioresource Technology 83: 1-11.

[17] Lau, M.W. and Dale, B.E. (2009). Cellulosic ethanol production from AFEX-treated corn stover using Saccharomyces cerevisiae 424A(LNH-ST). PNAS 106, 1368-1373.

[18] El-Zawawy, W.K., Ibrahim, M.M., Abdel-Fattah, Y.R., Soliman, N.A., Mahmoud, M.M. (2011). Acid and enzyme hydrolysis to convert pretreated lignocellulosic materials into glucose for ethanol production. Carbohydr. Polym. 84:865-871.

[19] Periyasamy, S., Venkatachalam, S., Ramasamy, S., and Srinivasan, V. (2009). Production of bioethanol from sugar molasses using Saccharomyces cerevisiae. Modern Applied Science 3(8): 32-37.

[20] Rosillo-Calle, F. and Johnson, F. (2010). The Food versus Fuel Debate: An Informed Introduction to Biofuels, Zed Books, London, UK.

[21] Ghosh, J.K., Delampady, M., Samanta, T. (2006). An Introduction to Bayesian Analysis: Theory and Method. Springer Science-Busines Media, New York.

[22] Koch, Karl-Rudolf. (2007). Introduction to Bayesian Statistic, 2nd., Springer-Verlag Berlin Heidelberg, Berlin.

[23] Pirard, R. (2016). Tantangan dan Peluang Pengembangan Bioenergi di Indonesia. Pusat Penelitian Kehutanan Internasional (CIFOR), Bogor.

[24] Bryson J.M. and Roaring W.D. (1987). Applying private sector strategic planning in the public sector. Journal of the American Planning Association 53: 9-22.

[25] European Commission. Evaluating socio-economic programmes. (1999). Principal evaluation techniques and tools. MEANScollection Vol. 3. Luxembourg: European Communities.

[26] Karppi I, Kokkonen M, La"hteenma"ki-Smith K. (2001). SWOTanalysis as a basis for regional strategies, Nordregio Working Paper Vol. 4. Nordregio - the Nordic Centre for Spatial Development, Stockholm.

[27] Terrados, J., Almonacid, G., and Hontoria, L. (2007). Regional energy planning through SWOT analysis and strategic planning tools. Impact on renewables development. Renewable and Sustainable Energy Reviews 11(6): 1275-1287.

[28] Srivastava, P.K., Kulshreshtha, K., Mohanty, C.S., Pushpangadan, P., Singh, A. (2005). Stake-holder-based SWOT analysis for successful municipal solid waste management in Lucknow, India. Waste Management 25(5): 531-537.

[29] European Commission. National. (2005). Sustainable development strategies in the European Union: a first analysis by the European Commission. Commission staff working document. http://ec.europa.eu/sustainable/docs/sustainable_development_strateg ies.pdf.

[30] Markovska, N., Taseska, V., and Pop-Jordanov, J. (2009). SWOT analyses of the national energy sector for sustainable energy development. Energy 34: 752-756. 
[31] Outlew et al. (2007). Economics of sugar-based ethanol production and related policy issues. Journal of Agricultural and Applied Economics Association, 39(2): 357-363.

[32] Morris, B.D. (2008). Economic Feasibility of Ethanol Production from Sweet Sorghum Juice In Texas. Thesis. Texas A\&M University, Texas.

[33] Salassi, M.E., and Breaux, J.B. (2006). Projected Costs and Returns -Sugarcane, Louisiana. LSU Agricultural Center, Dept. of Agricultural Economics and Agribusiness, A.E.A. Information Series No. 237.

[34] Shapouri, H. and Gallagher, P. (2005). USDA's 2002 Ethanol Costof-Production Survey, United State Department of Agriculture, Office of the Chief Economist, Office of Energy Policy and New Uses, Agricultural Economic Report No. 841.

[35] Herbst, Brian Keith. (2003). A The Feasibility of Ethanol Production in Texas. Thesis, Texas A\&M University.

[36] Ribera, L.A., Outlaw, J.L., Richardson, J.W., DaSilva, J. and Bryant, H. (2007). Integrating Ethanol Production into a U.S. Sugarcane Mill: A Risk-Based Feasibility Analysis. Agricultural and Food Policy Center, Department of Agricultural Economics, Texas A\&M University, College Station, Texas.

[37] Epplin, F.M. (1996). The cost to produce and deliver switchgrass biomass to an ethanol conversion facility on the southern plains of the United States. Biomass Bioenergy 11: 459-467.

[38] Graham, R.L., English, B.C. and Noon, C.E. (2000). A Geographical Information System-Based Modeling System for Evaluating the Cost of Delivered Energy Crop Feedstock. Biomass and Bioenergy 18(4): 309- 329.

[39] Mapemba, L.D., Epplin, F.M., Taliaferro, C.M., and Huhnke, R.L. 2007. Biorefinery feedstock production on conservation reserve program land. Review of Agricultural Economics 29(2): 227-46.

[40] Ahmadian-Moghadam, H., Elegado, F.B., Nayve, R. 2013. Prediction of ethanol concentration in biofuel production using Artificial Neural Networks. American Journal of Modeling and Optimization 1(3): 31-35.

[41] Gnansounou E, Dauriat A, Wyman CE. (2005). Refining sweet sorghum to ethanol and sugar: economic trade-offs in the context of North China. Bioresour Technol. 96(9): 985-1002.

[42] FAO. (2014). Food Outlook: Biannual Report on Global Food Markets. Food and Agriculture Organization of United Nations, Rome.

[43] Hillocks, et al. (2002). Brown streak disease of cassava in northern Mozambique caused by cassava brown streak virus. International Journal of Pest Management 48, 179-182.

[44] Danish Bioenergy Association. (2015). From sustainable biomass to competitive bioenergy: insights into danish bioenergy solutions. State of Green, Denmark.

[45] Dale, V. H., Efroymson, R.A., Kline, K.L., Davitt, M.S. (2015) Review: A framework for selecting indicators of bioenergy sustainability. Society of Chemical Industry and John Wiley \& Sons, Ltd | Biofuels, Bioprod. Bioref. 